\title{
Morphological and molecular description of a new record of Graneledone (Cephalopoda, Octopodidae) in the southeastern Pacific Ocean
}

\author{
Descripción morfológica y molecular de un nuevo registro de Graneledone (Cephalopoda, Octopodidae) \\ en el Océano Pacífico suroriental
}

\begin{abstract}
Christian M. Ibáñez ${ }^{1}$, M. Cecilia Pardo-Gandarillas ${ }^{1}$, Elie Poulin ${ }^{1}$ and Javier Sellanes ${ }^{2,3}$
${ }^{1}$ Instituto de Ecología y Biodiversidad, Departamento de Ciencias Ecológicas, Facultad de Ciencias, Universidad de Chile, Las Palmeras 3425, Ñuñoa, Santiago, Chile. ibanez.christian@gmail.com

${ }^{2}$ Departamento de Biología Marina, Facultad de Ciencias del Mar, Universidad Católica del Norte, Larrondo 1281, Coquimbo, Chile

${ }^{3}$ Centro de Investigación Oceanográfica en el Pacífico Sur-Oriental (COPAS), Universidad de Concepción, Casilla 160-C, Concepción, Chile
\end{abstract}

\begin{abstract}
Resumen.- Los pulpos del género Graneledone habitan en aguas profundas y constituyen 8 especies reconocidas. Se realizaron análisis filogenéticos de 4 especies de Graneledone con 2 marcadores moleculares (16S y COI), y se informa sobre un nuevo registro de Graneledone para el Océano Pacífico frente a la zona centro-sur de Chile. Se obtuvieron 4 ejemplares de Graneledone sp. entre 436 y 1482 m de profundidad. Estos pulpos son de tamaño medio, no tienen saco de tinta y tienen una sola fila de ventosas en sus brazos, que son de igual longitud. Se caracterizan por tener de 43 a 45 ventosas en el brazo hectocotilizado (tercero derecho); 6 a 7 laminillas por demibranquia; órgano del sifón en forma VV y de 5 a 7 pliegues transversales en la lígula. Algunos rasgos morfológicos muestran una gran variación en comparación con las especies del Pacífico, Atlántico y la Antártida. Los análisis filogenéticos moleculares apoyan la hipótesis de monofilia de Graneledone.
\end{abstract}

Palabras clave: Graneledone, pulpos de aguas profundas, zona batial, Chile

\begin{abstract}
Octopuses of the genus Graneledone inhabit in the deep-sea and are composed of 8 recognized species. Here we conduct phylogenetics analyses of 4 species of Graneledone using 2 molecular markers (16S and COI), and report a new record of Graneledone for the Pacific Ocean off south-central Chile. Four specimens of Graneledone sp. were collected from 436 to $1482 \mathrm{~m}$ depth. These octopuses are medium sized, have no ink sac and bear only one row of suckers in their arms, which are of similar length. They are characterized by having 43 to 45 suckers in the hectocotylized arm (third right); 6 to 7 lamellae per demibranch; VV-shaped funnel organ and 5 to 7 transverse creases in the ligulae. Some morphological traits show great variation compared with species from Pacific, Atlantic and Antarctic oceans. Molecular phylogenetic analysis supports the hypothesis of monophyly of Graneledone.
\end{abstract}

Key words: Graneledone, deep-sea octopuses, bathyal zone, Chile

\section{INTRODUCTION}

Octopuses of the genus Graneledone Joubin, 1898 generally live in the bathyal to abyssal zones ranging from $90 \mathrm{~m}$ to $2755 \mathrm{~m}$ depth and have been often reported occurring at particular ecosystems like hydrothermal vents and cold seeps (Voight 2000a, b, Guerrero-Kommritz 2000, 2006). Graneledone is composed of 8 recognized species (Norman \& Hochberg 2005) found in all the oceans: G. antarctica Voss, 1976 and G. macrotyla Voss, 1976 from the Antarctica, G. verrucosa (Verril, 1881) from the north Atlantic Ocean, G. gonzalezi Guerra, González \& Cherel 2000 from the Kerguelen Island, G. yamana Guerrero-Kommritz, 2000 from the southwest Atlantic, G. boreopacifica Nesis, 1982 from the north Pacific and G. taniwha O'Shea, 1999 and G. challengeri (Berry, 1916) from the south Pacific Ocean. The validity of certain species and sub-species is still controversial, as they have been classified based on highly variable morphological characters, making differentiating them very difficult. This genus is defined by having a body covered with warts, uniserial suckers, funnel organ VV shaped, no ink sac, crop reduced or absent, small gills, small posterior salivary glands, homodont radula, and in males terminal organ coiled in spiral and large ligulae in hectocotylus (O'Shea 1999, Guerrero-Kommritz 2000, Allcock et al. 2003). These 
character states are derived among Octopodidae suggesting the hypothesis of monophyly of Graneledone (Voight 1997, 2000a). Molecular divergence time estimation suggests that Graneledone originated in the southern ocean and their radiation into deep-sea was facilitated by the thermohaline circulation (Strugnell et al. 2008a). However, this molecular analysis only included 3 species: G. antarctica, G. verrucosa and G. boreopacifica.

Until now, Pareledone charcoti Joubin, 1905, Pareledone turqueti Joubin, 1905, Thaumeledone rotunda (Hoyle, 1885) and Graneledone antarctica were the only octopuses with uniserial suckers reported from Chilean waters $\left(18^{\circ} \mathrm{S}-56^{\circ} \mathrm{S}\right.$, Thore 1959 , Rocha 1997 , Vega et al. 2001, Vega 2009). However, recently specimens of Graneledone have been collected off south-central Chile, one of them in the vicinity of a bathyal methane seep site near Concepción ( 37ºS, Ibáñez et al. 2011). This site named Concepción Methane Seep Area (CMSA), has proven to be an abundance hotspot for both chemosymbiotic and heterotrophic fauna, and more than a hundred of megabenthic species have been recorded associated with it (Sellanes et al. 2004, 2008). Among this fauna, mollusks are one of the most important groups, with about 30 species present. In addition to common cephalopods (sepiolids and squids), unidentified incirrate octopod species belonging to Muusoctopus Gleadall 2004 (formerly Benthoctopus) and Graneledone genus occur it the CMSA and adjacent areas (Ibáñez et al. 2006, 2009, 2011).

In this study, we combine published data with new mitochondrial sequences to propose a phylogenetic hypothesis of the deep-sea octopuses of the genus Graneledone. Moreover, we describe a new record of Graneledone, comparing the type specimens both morphologically and genetically with their counterparts from the Pacific, Atlantic and Antarctic Oceans to further elucidate their taxonomic position.

\section{MATERIALS AND METHODS}

The present work was based on 4 Graneledone specimens captured off south-central Chile between $35^{\circ} \mathrm{S}$ and $38^{\circ} \mathrm{S}$ (Fig. 1). Octopuses of this genus are the only ones with uniserial suckers that have been reported so far for the Chilean margin (see Ibáñez et al. 2011). One of the specimens was collected by trawling during a cruise dedicated to the study of methane seep sites $\left(29^{\circ} \mathrm{S}-45^{\circ} \mathrm{S}\right)$. The remaining 3 specimens were obtained as by-catch from commercial fishing activities, one from the long-line

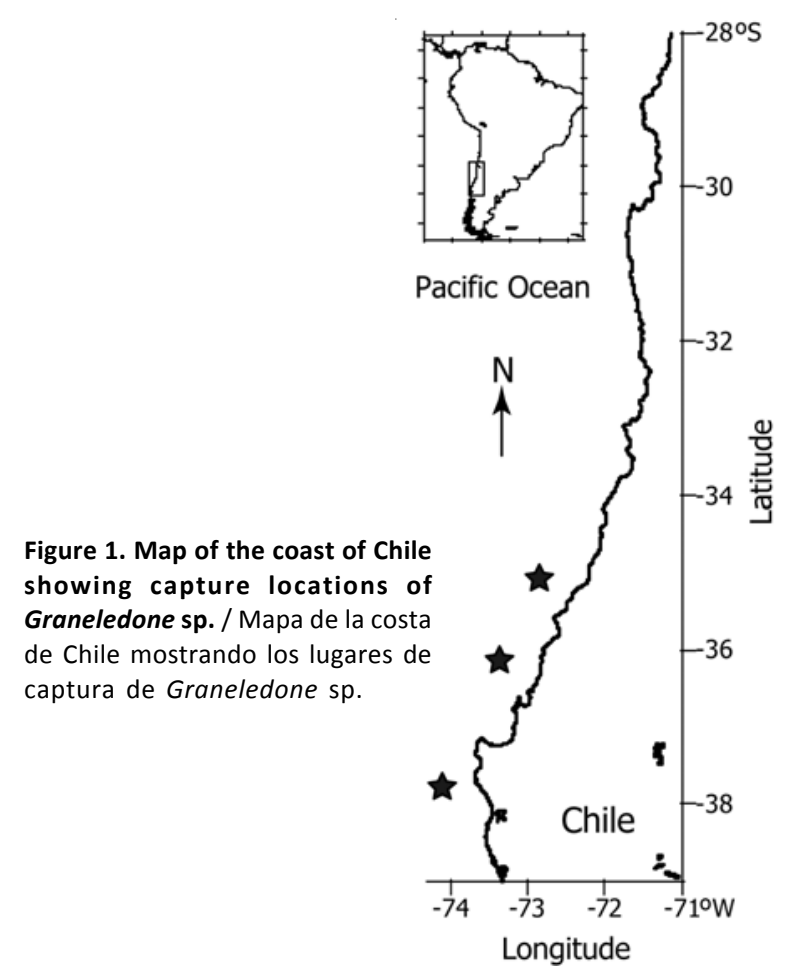

fisheries targeting the Patagonian toothfish (Dissostichus eleginoides Smith, 1898), and the other 2 from shrimp trawling. Tissue samples were fixed in $96 \%$ ethanol for molecular analysis and the whole animal in $10 \%$ seawater formalin for later anatomic and morphological analysis. The radula of the specimen MNHNCL6640 was dissected, mounted on tape, critical-point dried, coated under vacuum with gold and examined with a JEOL T-300 scanning electron microscope (SEM).

Description, measurements and counts followed Roper \& Voss (1983). Abbreviations used are the following: TL: total length; DML: dorsal mantle length; MW: mantle width; EO: eye diameter; HdL: head length; HdW: head width; AL: arm length 1 to 4R/L; WD: web depth A to E; ASC1-4: arm sucker count 1 to 4R/L; AS: arm sucker diameter; GiLC: gill lamella count; FuL: funnel length; FFL: free funnel length; CaL: calamus length; LL: ligula length; PAL: pallial aperture length; AW: arm base width; GiL: gill length; AF: arm formula; WF: web formula.

The specimens were deposited in the Museo Nacional de Historia Natural, Chile (MNHNCL), and Museo Zoológico de la Universidad de Concepción (MZUCUCCC). The comparative material examined is deposited in Zoological Museum of Hamburg (ZMH), Germany. 
Total DNA, to compare with other Graneledone species from GenBank, was extracted from 2 specimens following the saline extraction protocol (Aljanabi \& Martinez 1997). PCR amplifications were carried out using for each sample $0.3 \mu \mathrm{l}$ of Taq DNA polymerase and $2.5 \mu \mathrm{l}$ commercially supplied buffer, with $2 \mu \mathrm{l}$ dNTPs, and $0.5 \mu \mathrm{l}$ of each primers LCO1490 and HCO2198 for Cytochrome Oxidase I (COI) and 16SF and 16SR for 16S rRNA (see primers in Allcock et al. 2008). After an initial denaturation ( $3 \mathrm{~min}$ at $94^{\circ} \mathrm{C}$ ), the reaction mixtures were subjected to 35 cycles of $94^{\circ} \mathrm{C}(40 \mathrm{~s}), 50^{\circ} \mathrm{C}(40 \mathrm{~s})$ for COI and $52^{\circ} \mathrm{C}(40 \mathrm{~s})$ for $16 \mathrm{~S}$, and $72^{\circ} \mathrm{C}(60 \mathrm{~s})$ followed by a final extension at $72^{\circ} \mathrm{C}$ (7 min) using a thermal cycler. PCR products were purified by the Wizard ${ }^{\mathrm{TM}}$ Prep system (Promega) following the manufacturer's protocols. Purified PCR products were sequenced by Macrogen Inc. Sequences were aligned using Clustal W implemented in MEGA 5.0 software (Tamura et al. 2011).

Phylogenetic reconstruction and distances between species were calculated from a matrix including the concatenated dataset (16S + COI). For this purpose, we determined the congruence on the phylogenetic signal of the genes with the ILD test (Farris et al. 1995), implemented in the partition homogeneity test of PAUP* version 4.0b (Swofford 2002). Parsimony (P) and maximum likelihood (ML) methods, and Bayesian inference (BI) were applied to the evaluation of phylogenetic relationships of Graneledone species. The evolutionary model that best fit the data was d GTR $+\Gamma+\mathrm{I}$ model $(\mathrm{AIC}=4067.15$, - $\ln L=2016.57)$, determined by the Akaike Information Criterion (AIC) as implemented by JModelTest (Posada 2008). Bayesian analyses were conducted using MrBayes v3.2 (Ronquist et al. 2012) with four default heated chains, each with five million generations, sampled every 1000 generations. Runs were checked for convergence see the likelihood using the Tracer version 1.5 (Rambaut \& Drummond 2009). The first 500 trees of each run were discarded as burn-in, and a consensus of the remaining trees was computed for the final outcome. Parsimony and ML analyses were carried out in PAUP* (Swofford 2002) (heuristic search, tree bisection-reconnection) and support for nodes was estimated by bootstrapping with 10,000 pseudo-replicates (Felsenstein 1985), providing an estimate of the confidence limits for the resulting topologies. Finally, we used FigTree 1.3.1 to edit the trees (Rambaut 2009). To construct these trees we used Pareledone charcoti (Joubin, 1905), P. turqueti (Joubin, 1905), Megaleledone setebos (Robson, 1932), Thaumeledone peninsulae Allcock et al. 2004, T. rotunda
Table 1. Octopod species included in the phylogenetic analyses / Especies de octópodos incluidas en los análisis filogenéticos

\begin{tabular}{lcc}
\hline \multicolumn{1}{c}{ Species } & COI & 16S rRNA \\
\hline Graneledone sp.1 MNHNCL 6641 & JN800404 & JN800402 \\
Graneledone sp.2 MZUC-UCCC 32743 & JN800403 & JN800401 \\
Graneledone antarctica Voss, 1976 & AF377973 & EU071436 \\
Graneledone verrucosa 1 (Verril, 1881) & EU071449 & AY545111 \\
Graneledone verrucosa 2 (Verril, 1881) & AF000042 & DQ093490 \\
Graneledone boreopacifica 1 Nesis, 1982 & EU071448 & EU071435 \\
Graneledone boreopacifica 2 Nesis, 1982 & EU071449 & --- \\
Thaumeledone rotunda (Hoyle, 1885) & EU071445 & EU071432 \\
Thaumeledone gunteri Robson, 1930 & AY557521 & AF299266 \\
Thaumeledone peninsulae Allcock et al. 2004 & EU071446 & EU071433 \\
Adelieledone polymorpha (Robson, 1930) & EF102173 & EF102194 \\
Adelieledone piatkowski Allcock et al. 2003 & EU071444 & EU071431 \\
Pareledone charcoti (Joubin, 1905) & EF102175 & EF102196 \\
Pareledone turqueti (Joubin, 1905) & EF102192 & EF102213 \\
Megaleledone setebos (Robson, 1932) & EF102174 & EF102195 \\
\hline
\end{tabular}

(Hoyle, 1885) and T. gunteri Robson, 1930 as outgroups and the phylogenetic tree is rooted using Adelieledone polymorpha (Robson, 1930) and A. piatkowski Allcock et al. 2003 since these species are basal to Graneledone (Strugnell et al. 2008 a,b). Sequences generated in this study are available from GenBank (Table 1).

\section{SySTEMATICS}

Family Octopodidae d’Orbigny, 1840

Genus Graneledone Joubin, 1918

Graneledone sp. (Figs. 2-6)

\section{Diagnosis}

Sucker row uniserial. Ink sac absent. Funnel organ VVshaped. Hectocotylus clearly differentiated into calamus and ligula; the latter with or without creases. Terminal organ (penis) coiled in spiral. Gills small, with 5-9 lamellae per demibranch. Radula homodont or heterodont. Salivary glands small. Wart-like tubercles cover dorsal surfaces of mantle, head, arms and web.

Type species: Graneledone verrucosa (Verril, 1881)

Synonymy: Eledone verrucosa Verrill, 1881, Moschites verrucosa Berry, 1917.

\section{Material eXamined}

Adult male $110 \mathrm{~mm}$ ML (North off Mocha island, 37\%46.17'S, 7407.29'W, southeastern Pacific, $1482 \mathrm{~m}$ depth) MNHNCL 6641. Collected by J. Sellanes, October 2007. Adult male 160 mm ML (off Constitución coast, caught by shrimp 


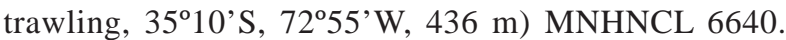
Collected by C.M. Ibáñez, October 2000. Adult female 165 mm ML (Northwest off Concepción, caught by a fishing line, 36¹5.71'S, 7343.48'W, 600 m) MZUC-UCCC 32743. Collected by M. Pedraza, March 2007. Adult male $80 \mathrm{~mm}$ ML (from southern Chile, caught by shrimp trawling) MNHNCL 300039 (without collecting data).

\section{COMPARATIVE MATERIAL EXAMINED}

Graneledone antarctica, adult male $55 \mathrm{~mm} \mathrm{ML}$ (Antarctica, 74³1'54'’S, 027¹3'24'’W, 2103 m) ZMH 12658, collected during RV Polarstern cruise Antarktis XV/ 3 at station 134 in 1998. Graneledone antarctica, adult female 60 mm ML (Antarctica, 69²5'00'”S, 005²0’00”'W, 1800 m) ZMH 72401, collected during RV Polarstern cruise Antarktis XXIII/2 at station 57 in 2005. Graneledone verrucosa, two females 46 and $17 \mathrm{~mm}$ ML, (NE Atlantic, 4946’00”N, 012³1'00'”W, 2000 m) ZMH 12657, collected during RV Walther Herwig cruise \#47 at station 630 in 1981. Graneledone verrucosa, adult female $98 \mathrm{~mm}$ ML (N Atlantic, $1200 \mathrm{~m}), \mathrm{ZMH}$ 12663, collected during RV Walther Herwig cruise \#46 at station 591 in 1981. Graneledone yamana, adult male $50 \mathrm{~mm} \mathrm{ML}$ (SE to Falkland Islands, 54¹8'00'’S, 56¹0'00'”W, 560 m) ZMH 12669, collected during RV Walther Herwig cruise \#31 at station 584 in 1978. Graneledone yamana, adult male 58 mm ML (near to Falkland Islands, 50¹8'00'' $\mathrm{S}$, 5649'00'”W, $515 \mathrm{~m}$ ) ZMH 2789, collected during RV Walther Herwig cruise \#45 at station 325 in 1966.

\section{Diagnosis}

Medium sized octopus (TL $=520$ to $810 \mathrm{~mm}$ ) lacking ink sac. Suckers small and uniserial (6-8 mm maximum diameter). Eyes large (20\% of DML) and projecting. Funnel organ VV shaped, free zone of the funnel corresponding to $53-62 \%$ of funnel length. First pair of arms always longest (75-78\% of TL), with arm formula 1.2.3.4.; web very deep, sectors unequal; sector A and B always largest and sector $\mathrm{E}$ smallest. Third right arm of males hectocotylized with 43 and 45 suckers and shorter than opposite arm. The opposite arm with 98 to 107 suckers. Calamus of medium size (50\% of the ligula) with deep median incision; ligula without copulatory lamellae, but with 5 to 7 creases. Six to 7 lamellae per demibranch. Radula bearing 7 teeth: 3 central, 2 lateral and 2 marginal plates in each transversal line. Body surface covered by complex papillose warts with many tiny spine-like structures covering body dorsally from mantle to arm tips. Thirty to 35 warts at the dorsal mantle midline from anterior to posterior and 15 to 20 between the eyes. These warts composed of 1 to 5 individual processes. Two clusters of 18-22 warts above each eye.

\section{DESCRIPTION}

Adult specimens examined are of medium size (TL 520 to $810 \mathrm{~mm}$ ). Mantle sacciform (up to $100 \mathrm{~mm} \mathrm{ML)} \mathrm{(Fig.} \mathrm{2A).}$ Body surface covered by complex papillose warts with many tiny spine-like structures covering body dorsally from mantle to arm tips (Figs. 2A, 5A-B). Thirty to 35 warts at the dorsal mantle midline and 15 to 20 between the eyes. These warts are clustered between 1 to 4 individual processes in the mantle and webs. Over each eye, two groups of 18 to 22 individual processes (Fig. 5B). These clusters are 1 to $5 \mathrm{~mm}$ in diameter. Pallial aperture moderately wide with respect to the mantle width (41-62\% of ML). Head width similar to mantle (95 to 100\% of MW). Eyes relatively large (diameter $=22$ to $32 \mathrm{~mm}$ ), located in a more lateral than frontal position, almost at the same level of the dorsal surface. Funnel medium sized (28 to 36\% of ML); funnel free portion is very short represents 53 to $62 \%$ of the funnel total length. Funnel organ is ' $\mathrm{VV}$ ' shaped, with internal components wider and longer than external ones (Figs. 2B, 5D).

Arms long and similar in length, generally not exceeding $78 \%$ of the TL, with the first pair always being the longest, and the fourth pair the shortest. Typical arm formula 1.2.3.4. Arms narrow and sharpened to the ends (14 to $18 \%$ of ML) (Table 2). Web short with E sector shortest. Web formula BCADE, ACDBE and ABCDE (Table 2).

Arms with uniserial suckers (Fig. 2A, 5C). Suckers small, tubular, sessile and without acetabulum aperture (4.2 to $5.4 \%$ of ML). Third right arm hectocotylized (53 to $48 \%$ of TL), being shorter in length than its opposite (57 to 64\% of TL) (Table 2, Fig. 2A-C, 5E). Suckers on the hectocotylized arm number between 43 and 45; opposite arm carries between 98 and 107 (Table 2). Spermatophoric canal smooth and without pigmentation, extending along ventral face of hectocotylized arm ending in the calamus. Copulatory organ with a small ligula (3.2 to $4.1 \%$ of hectocotylized arm), with 5 to 7 transverse creases (Figs. 2C, 5E). Calamus (8 to $9 \mathrm{~mm}$ ) without pigmentation and slightly long (50\% of ligula length). Gills small with six to seven lamellae per demibranch.

Anterior salivary gland small (4 mm); posterior salivary glands small (6 mm); esophagus slender, pseudocrop without diverticulum, stomach muscular; caecum small and striated coiled in a single whorl; large digestive gland 
Table 2. Measurements $(\mathrm{mm})$ and counts of Graneledone sp. For abbreviations see Materials and Methods. *Incomplete or damaged organ / Medidas $(\mathrm{mm})$ y conteos de Graneledone sp. Para abreviaciones ver Materiales y Métodos. *órgano dañado o incompleto

\begin{tabular}{|c|c|c|c|c|}
\hline & MNHNCL 6640 & MZUC-UCCC 32743 & MNHNCL 6641 & MNHNCL 300039 \\
\hline Sex & Male & Female & Male & Male \\
\hline TL & 810 & 760 & 520 & 330 \\
\hline AL11 & 630 & 570 & 395 & 248 \\
\hline ALlr & 565 & 564 & 380 & 245 \\
\hline AL2l & 590 & 570 & 375 & $220 *$ \\
\hline AL2r & 560 & 570 & $300 *$ & 240 \\
\hline AL31 & 465 & 466 & 335 & 178 \\
\hline AL3r & 390 & 495 & 278 & 170 \\
\hline AL4l & 255 & 463 & 310 & 170 \\
\hline AL4r & 439 & 442 & 300 & 160 \\
\hline AW & 23 & 28 & 20 & 20 \\
\hline HW & 88 & 101 & 90 & 60 \\
\hline HL & 45 & 51 & 43 & 25 \\
\hline MW & 93 & 130 & 90 & 75 \\
\hline DML & 160 & 165 & 110 & 80 \\
\hline VML & 95 & 100 & 93 & 50 \\
\hline PA & 66 & 86 & 68 & 50 \\
\hline ED & 32 & 32 & 22 & 12 \\
\hline SD & 8 & 7 & 6 & 5 \\
\hline LL & 16 & --- & 9 & 6 \\
\hline $\mathrm{CaL}$ & 8 & --- & 8.5 & 4 \\
\hline $\mathrm{FuL}$ & 47 & 47 & 40 & 35 \\
\hline FfuL & 29 & 27 & 21 & 15 \\
\hline GiLC & 7 & 6 & 7 & 7 \\
\hline WDA & 90 & 105 & 78 & 60 \\
\hline WDBI & 100 & 78 & 70 & 48 \\
\hline WDCl & 90 & 100 & 65 & 38 \\
\hline WDDl & 85 & 80 & 50 & 55 \\
\hline WDBr & 114 & 78 & 55 & 56 \\
\hline WDCr & 95 & 70 & 50 & 40 \\
\hline WDDr & 85 & 57 & 55 & 59 \\
\hline WDE & 85 & 48 & 30 & 65 \\
\hline WF & $\mathrm{B}>\mathrm{C}>\mathrm{A}>\mathrm{D}=\mathrm{E}$ & ACDBE & $\mathrm{ABCDE}$ & EABDC \\
\hline $\mathrm{AF}$ & 1234 & 1234 & 1234 & 1243 \\
\hline FO & VV & VV & VV & VV \\
\hline ASC1R & 100 & 87 & 102 & 73 \\
\hline ASC1L & 61 & 99 & 95 & 75 \\
\hline ASC2R & 104 & 97 & $45^{*}$ & 78 \\
\hline ASC2L & 79 & 104 & 108 & 74 \\
\hline ASC3R & 43 & 95 & 45 & 43 \\
\hline ASC3L & 98 & 105 & 107 & 70 \\
\hline ASC4R & 88 & 100 & 90 & 69 \\
\hline ASC4L & 82 & 95 & 93 & 63 \\
\hline
\end{tabular}



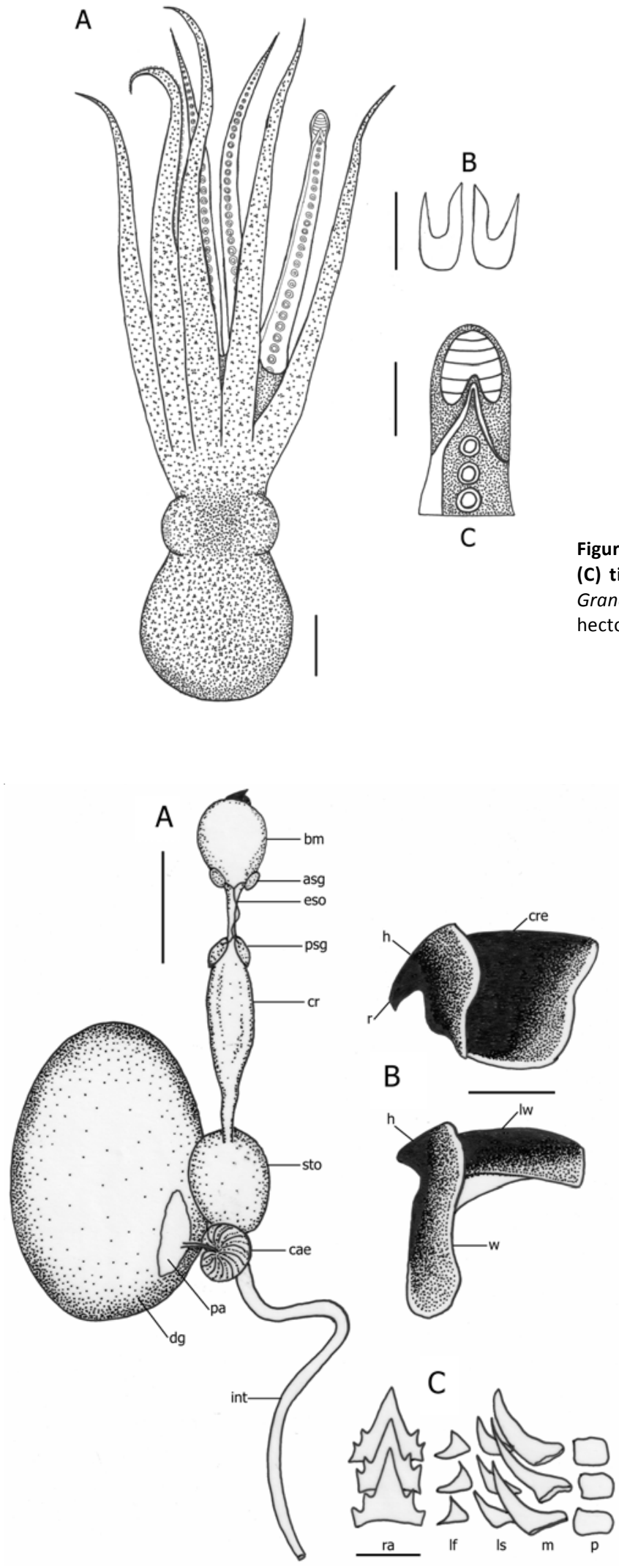

Figure 2. Graneledone sp. (MNHNCL 6641). (A) adult male, (B) funnel organ, (C) tip of the hectocotylus. Scale bars: A, $30 \mathrm{~mm}$; B, $30 \mathrm{~mm} ; C, 8 \mathrm{~mm} /$ Graneledone sp. (MNHNCL 6641). (A) macho adulto, (B) órgano del sifón, (C) hectocotilo. Escala de barras: A, $30 \mathrm{~mm}$; B, $30 \mathrm{~mm}$; C, $8 \mathrm{~mm}$
Figure 3. Digestive tract of Graneledone sp. (A) Digestive tract; asg, anterior salivary glands; eso, oesophagus; cr, crop; sto, stomach; cae, caecum; bm, buccal mass; psg, posterior salivary glands; dg, digestive gland; pa, pancreas; int, intestine, (B) beaks; $r$, rostrum; $h$, hood; cre, crest; lw, lateral wing; $w$, wing; (C) radula; $p$, plate; $m$, marginal tooth; Is, second lateral tooth; If, first lateral tooth; ra, rachidian teeth. Scale bars: A, $10 \mathrm{~mm}$;, $20 \mathrm{~mm}$;, $\mathbf{1} \mathrm{mm} /$ Tracto digestivo de Graneledone sp. (A) Tracto digestivo; asg, glándulas salivares anteriores; eso, esófago; cr, buche; sto, estómago; cae, ciego; bm, masa bucal; psg, glándulas salivares posteriores; dg, glándula digestiva; pa, páncreas; int, intestino, (B) picos; r, rostro; $h$, capucha; cre, cresta; Iw, ala lateral; $w$, ala; (C) rádula; $p$, placa; $\mathrm{m}$, diente marginal; Is, diente lateral secundario; If, diente lateral primario; ra, diente raquídeo. Escala de barras: A, $10 \mathrm{~mm}$; B, 20 $\mathrm{mm} ; \mathrm{C}, 1 \mathrm{~mm}$ 
Figure 4. Reproductive system of Graneledone sp. (A) female reproductive system; do, distal oviduct; og, oviductal gland; po, proximal oviduct; ov, ovary, (B) egg, (C) male reproductive system; ag, accessory gland; sgl, spermatic gland; tes, testis; ns, Needham's sac; to, terminal organ, (D) spermatophore. Scale bars: A, $10 \mathrm{~mm}$; B, $2 \mathrm{~mm}$; C, $20 \mathrm{~mm}$; D, $15 \mathrm{~mm}$ / Sistema reproductivo de Graneledone sp. (A) sistema reproductivo de hembra; do, oviduct distal; og, glándula oviductal; po, oviduct proximal; ov, ovario, (B) huevo, (C) sistema reproductivo de macho; ag, glándula accesoria; sgl, glándula espermática; tes, testículo; ns, saco de Needham; to, órgano terminal, (D) espermatóforo. Escala de barras: A, $10 \mathrm{~mm}$;, $2 \mathrm{~mm}$; C, $20 \mathrm{~mm}$;, $15 \mathrm{~mm}$
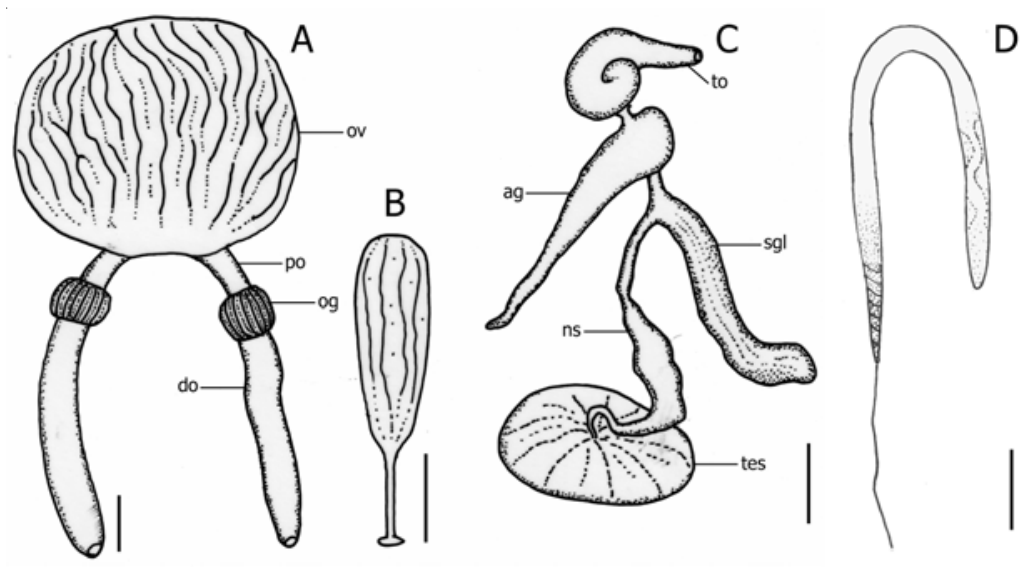

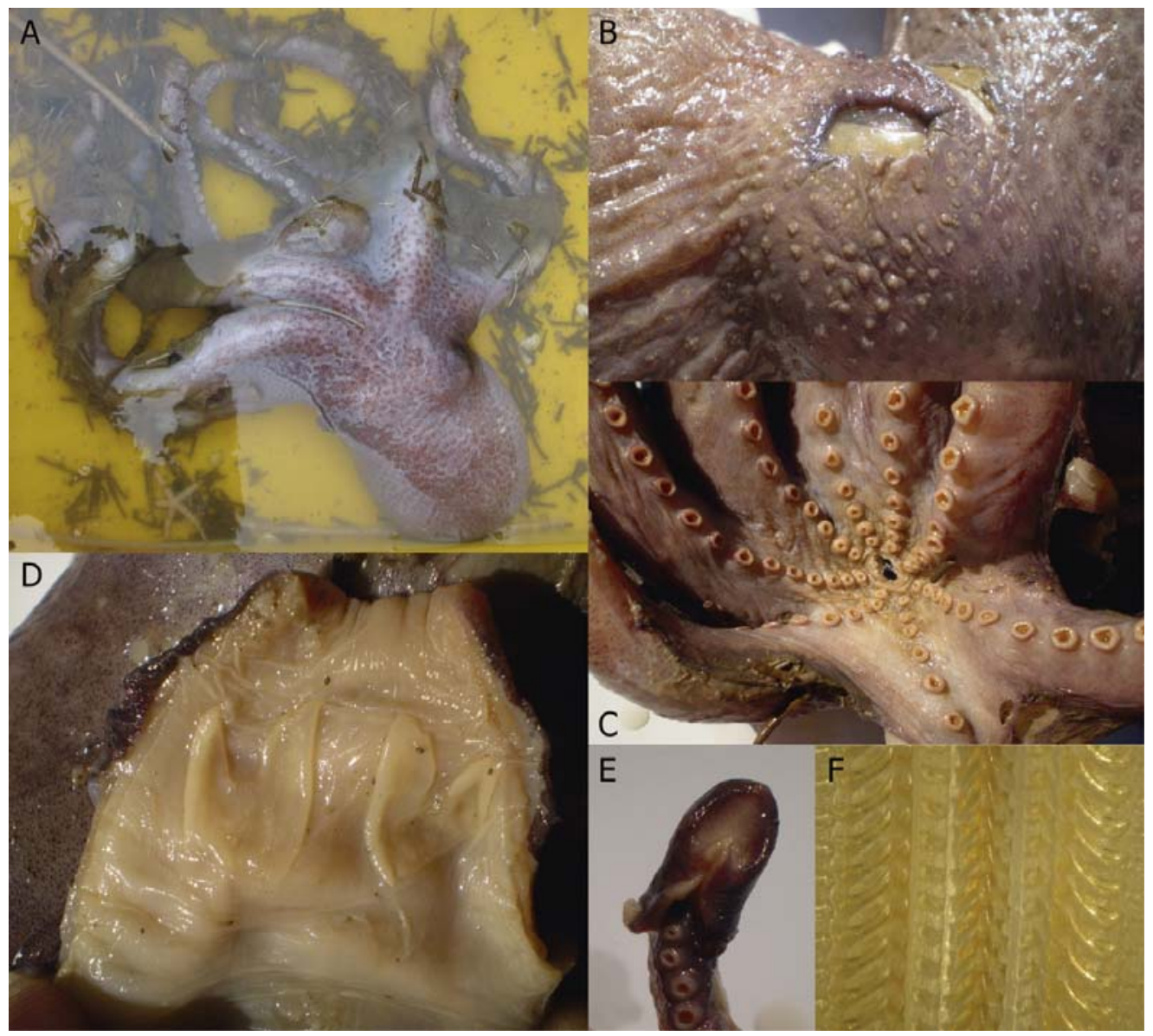

Figure 5. Photographs of Graneledone sp. (MNHNCL 6641). (A) fresh specimen, (B) eye, (C) suckers, (D) funnel organ, (E) hectocotylus, (F) radulae. Scale bars: A, $\mathbf{3 0} \mathrm{mm}$;, $\mathbf{2 0} \mathbf{~ m m ; ~ C , ~} \mathbf{5 m m}$ D, $\mathbf{2 0 ~ m m ; ~ E , ~} 10$ mm; F, $\mathbf{1 ~ m m ~ / ~ F o t o g r a f i ́ a s ~ d e ~ G r a n e l e d o n e ~ s p . ~ ( M N H N C L ~ 6 6 4 1 ) . ~ ( A ) ~ e s p e ́ c i m e n ~}$ fresco, (B) ojo, (C) ventosas, (D) órgano del sifón, (E) hectocotilo, (F) rádula. Escala de barras: A, $30 \mathrm{~mm} ; \mathrm{B}, 20 \mathrm{~mm} ; \mathrm{C}, 5 \mathrm{~mm} ; \mathrm{D}, 20 \mathrm{~mm} ; \mathrm{E}, 10$ $\mathrm{mm} ; \mathrm{F}, 1 \mathrm{~mm}$ 
(43 mm) roundish without ink sac; intestine long (107 $\mathrm{mm}$ ) without anal flaps (Fig. 3A). Upper beak with strong deep jaw angle; lower beak with distinct groove along lower edge of insertion plate (Fig. 3B). Radula with a multicuspid rachidian, and to each side two lateral teeth, one marginal tooth and the marginal plate (Fig. 3C, 5F, $6 \mathrm{~A}, 6 \mathrm{~B})$.

Genitalia of female with large ovary (41 mm diameter); oviductal gland large (11 mm diameter); distal oviduct large (51 mm length) (Fig. 4A). 55 eggs (10-12 mm long) in ovary of maturing female (Fig. 4B).

Male reproductive system with short, thick proximal vas deferens; spermatophoral gland moderately long $(60 \mathrm{~mm})$ (Fig. 4C). Accessory gland large $(40 \mathrm{~mm})$, with terminal recurvature. Spermatophore sac long, containing four spermatophores (160-180 mm) (Fig. 4D). Poor preservation condition of the spermatophores did not allow further detailed description. Distal vas deferens short, penis diverticulum large with spiral, penis large (25 mm) (Fig. 4C).

Locations. Southeastern Pacific Ocean, north of Mocha

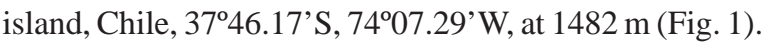

Distribution. Southeastern Pacific Ocean, from $35^{\circ} \mathrm{S}$ $38^{\circ} \mathrm{S}, 436$ to $1482 \mathrm{~m}$ depth (Fig. 1).

Habitat. Upper continental slope, associated with hard grounds (e.g., at methane seep sites).

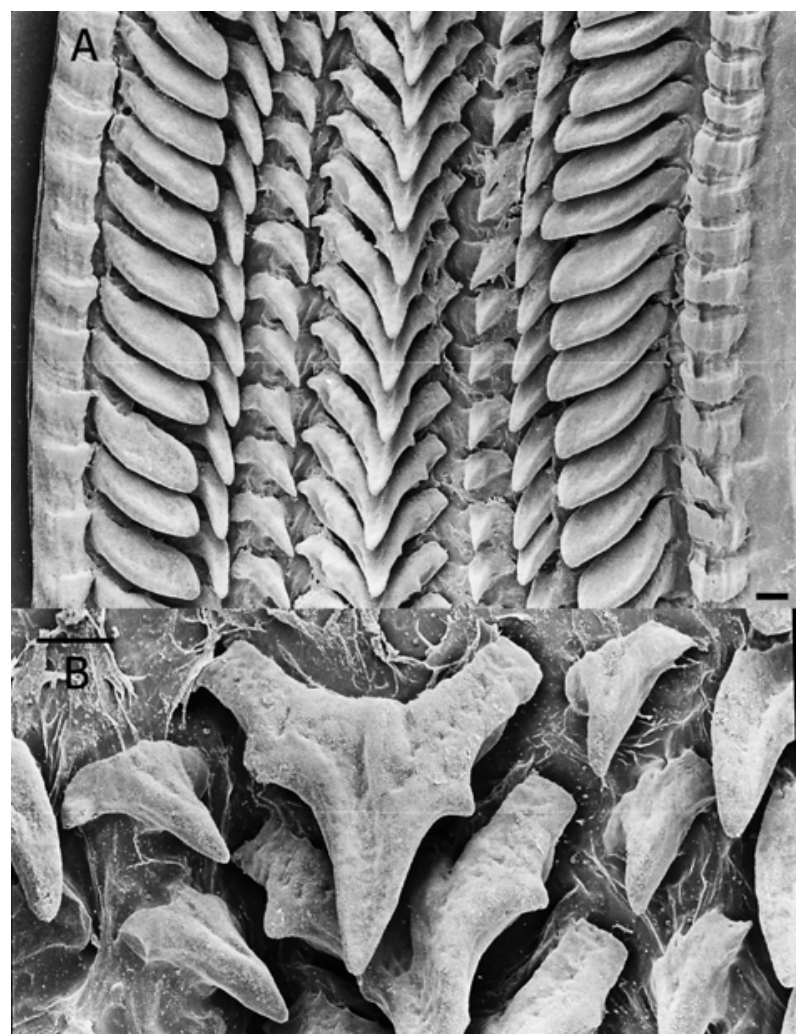

Figure 6. Radula of Graneledone sp. (MNHNCL 6640). (A) general view, (B) detail of the rachidian tooth. Scale bars $0.1 \mathrm{~mm} /$ Rádula de Graneledone sp. (MNHNCL 6640). (A) vista general, (B) detalle del diente raquídeo. Escala de barras $0,1 \mathrm{~mm}$

Table 3. Morphological comparison between Graneledone species / Comparación morfológica entre las especies de Graneledone

\begin{tabular}{|c|c|c|c|c|c|c|c|}
\hline Species & $\begin{array}{l}\text { Ocular } \\
\text { cirri }\end{array}$ & $\begin{array}{l}\text { Gills } \\
\text { count }\end{array}$ & ASC & HASC & $\begin{array}{l}\text { Warts } \\
\text { mantle }\end{array}$ & $\begin{array}{l}\text { Warts } \\
\text { head }\end{array}$ & Reference \\
\hline Graneledone sp. & Absent & $6-7$ & $61-108$ & $43-45$ & $30-35$ & $15-20$ & This study \\
\hline G. antarctica & Absent & $5-6$ & $49-63$ & 39 & $25-36$ & $23-27$ & Voss 1976 , O'Shea 1999 , this study \\
\hline G. gonzalezi & Absent & 6 & $29-72$ & $32-40$ & 20 & 10 & Guerra et al. 2000 \\
\hline G. yamana & Present & $5-7$ & $35-80$ & $26-38$ & $10-15$ & $4-6$ & Guerrero-Kommritz 2000 , this study \\
\hline G. macrotyla & Present & 7 & $32-65$ & $31-40$ & $10-12$ & - & $\begin{array}{c}\text { Voss 1976, Kubodera and Okutani } \\
\text { 1994, Guerra et al. } 2012\end{array}$ \\
\hline G. boreopacifica & Present & $7-8$ & $60-82$ & $36-38$ & $21-29$ & $15-18$ & Voss and Pearcy 1990 \\
\hline G. challengeri & Absent & $6-7$ & $73-114$ & $41-51$ & $30-40$ & $20-30$ & O'Shea 1999 \\
\hline G. verrucosa & Present & $6-8$ & $58-87$ & $40-46$ & $18-26$ & $10-16$ & Allcock et al. 2003, this study \\
\hline G. taniwha taniwha & Absent & $7-8$ & $58-97$ & $39-45$ & $24-29$ & $12-15$ & O'Shea 1999 \\
\hline G. taniwha kubodera & Absent & $7-8$ & $71-99$ & $44-48$ & $23-25$ & $11-14$ & O'Shea 1999 \\
\hline
\end{tabular}

ASC $=$ arm sucker count, HASC $=$ hectocotylized arm sucker count 


\section{MORPHOLOGICAL COMPARISON}

Some morphological characters distinguish Graneledone sp. from other congeneric species. The presence of supraocular cirri in G. boreopacifica, G. verrucosa, G. macrotyla and G. yamana contrasts with the absence of these structures in $G$. sp. Counts of cartilaginous clusters along the mantle and head are higher in individuals of $G$. sp. than in G. gonzalezi, G. macrotyla, G. yamana, G. boreopacifica, $G$. verrucosa and $G$. taniwha, but less than in G. antarctica and G. challengeri (Table 3). The numbers of wart processes within each cluster in $G$. sp. are higher (1-22 units) and larger (diameter 1-5 mm), than in $G$. antarctica (1-11 units) (diameter 0.3-0.9 mm), G. gonzalezi (1-12 units) (diameter $3.3 \mathrm{~mm}$ ), G. boreopacifica (3-12 units) (diameter 1-3 mm), G. verrucosa (1-12 units) (diameter 1-3 $\mathrm{mm}$ ) and $G$. challengeri (1-10 units) (diameter 1-2.7 mm) and less than $G$. taniwha (1-37 units) (diameter 0.5-8 mm). Moreover, Graneledone sp. have 5-7 transverse creases in the ligulae, while G. gonzalezi, G. yamana, G. boreopacifica, G. verrucosa, G. challengeri lacks them. Graneledone taniwha taniwha have 7-8 transverse creases in the ligulae, while G. antarctica have 9-13, higher count than in $G$. sp., but $G$. taniwha kubodera have less (3-4) than G. sp. Hectocotylized sucker count is very close between $G$. sp. and $G$. challengeri, $G$. verrucosa and $G$. taniwha, but higher than other species (Table 3).

\section{MolecUlaR PHYLOgENETIC ANALYSIS}

Alignment lengths for COI and 16S rRNA fragments were 655 bp and 497 bp, respectively. Partition homogeneity test did not show significant differences between these molecular markers $(P=0.21)$, and sequences were combined and analyzed as a single data set. The combined data (16S + COI) of 1152 bp length contained 71 characters that were parsimony informative. The Graneledone sp. specimens differed by 9 substitutions (0.8\%) from $G$. boreopacifica, and by 14 substitutions (1.2\%) from $G$. verrucosa and 27 (2.3\%) from G. antarctica. Comparing G. boreopacifica with $G$. verrucosa we found only 17 substitutions (1.5\%). The only $16 \mathrm{~S}$ rRNA sequence of $G$. taniwha from South West Pacific Ocean (GenBank accession number AJ311119) showed a substantial divergence (4.2\%) with $G$. sp. Unfortunately, we are not sure if this sequence corresponds to some G. taniwha species because there is no collection information associated to the record.

All phylogenetic analyses (P, ML, BI) depict a similar tree topology with some slightly differences in node support by bootstrap and posterior probabilities (Fig. 7).

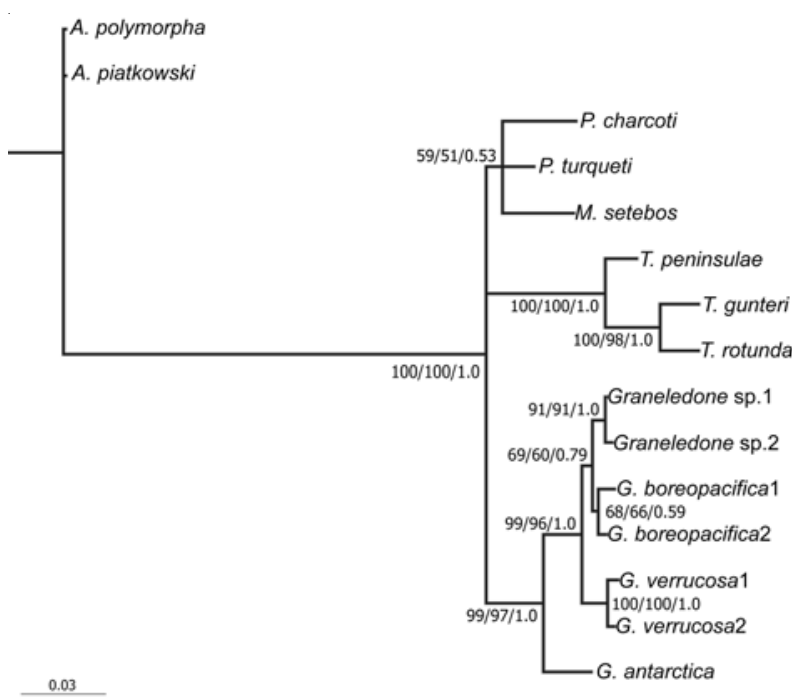

Figure 7. Bayesian phylogram of Graneledone species (16S+COI). Node values are bootstrap of 10,000 iterations of MP and ML, and posterior probabilities of BI / Filograma Bayesiano de las especies de Graneledone (16S+COI). Valores en los nodos son el resultado de bootstrap de 10.000 iteraciones de $\mathrm{P}$ y $\mathrm{ML}$, y probabilidades a posteriori de $\mathrm{BI}$

These high nodes values support the hypothesis of monophyly of Graneledone (Fig. 7). Graneledone boreopacifica was the sister species of Graneledone sp. (Fig. 7).

We found a ML tree of $-\ln L=1159.72$. Maximum parsimony analysis using the combined data set $(16 \mathrm{~S}+\mathrm{COI})$ returned one parsimonious tree, 212 steps in length (consistency index excluding uninformative sites $=0.761$; retention index $=0.802$ ).

\section{Discussion}

Morphological, molecular and phylogenetic analysis of mtDNA sequences of the Chilean Graneledone specimens and those of North Pacific, North Atlantic and Antarctica supported the taxonomic distinctiveness of these specimens as a candidate species. However, further revision of the holotype and/or paratypes of the other species of Graneledone are needed to confirm the identity of Graneledone from Chile. Holotypes of Graneledone species are in France, Russia, England, Germany and New Zealand (Sweeney 2001) making them very difficult to access and study for Southern Hemisphere researchers.

The great genetic similarity between Graneledone species is due to their recent origin, estimated to be about 3 million years (Strugnell et al. 2008a). Similar low 
differentiation between inter-species comparisons was detected in the related octopodid genus Pareledone (12\%; Allcock et al. 2007) and Thaumeledone (2-3.3\%; Strugnell et al. 2008b). The phylogenetic relationship is very consistent with the hypothesized monophyly of Graneledone (Voight 2000a) and the Antarctic origin of these deep-sea octopuses (Strugnell et al. 2008a), because G. antarctica is the most basal species of Graneledone and the Atlantic and Pacific species are the most derivated and the divergence of Pacific species could be very recent. Sequences of all Graneledone species are needed to complete the phylogenetic reconstruction, establish their origin and the divergence of these deep-sea species.

The great variation in morphometric and meristic data in species of the genus Graneledone (Table 3) complicates the identification, given the overlap in counts of gills, suckers and warts among different species. Multivariate analysis of the morphological dataset suggests that these counts and indices, traditionally used for discriminating between cephalopods species, do not show great discrimination at species level, but provide excellent discrimination at the generic level (Allcock et al. 2008). The difficulty differentiating between Graneledone sp. and their relatives is consistent with the idea of cryptic species, and as mentioned earlier, could be a consequence of the recent origin of the group. Voight (2000a) commented on the possible existence of cryptic species of Graneledone within the north Pacific specimens collected at different depths. Cryptic speciation in octopuses has been reported in other genera like Octopus and Pareledone (Söller et al. 2000, Allcock et al. 2011), and could be more common than previously thought.

The records of octopus with uniserial suckers from Chile had many problems. Roper et al. (1984) mentioned Pareledone spp. with circumpolar distributions including the coast of southern Chile, Argentina and South Africa, leading Rocha (1997) to include Pareledone charcoti and $P$. turqueti in the check list of cephalopods from Chile. Guerrero-Kommritz (2006) reviewed the octopods with uniserial suckers from southwest Atlantic and finds a very diverse octopus fauna including Eledone, Graneledone, Vosseledone, Thaumeledone, and Pareledone. However, we studied up to $2500 \mathrm{~km}$ of Chilean coast and the only octopuses with uniserial suckers were Graneledone (see Ibáñez et al. 2011). Thore (1959) reported a specimen of Bentheledone rotunda (Hoyle 1885) (now Thaumeledone rotunda) off Valparaíso, Chile $\left(33^{\circ} \mathrm{S}, 71^{\circ} \mathrm{W}\right)$, but he mentioned that the identification must be considered dubious, since H.M.S. Challenger only captured the arms of the octopus. This specimen could have corresponded indeed to Graneledone sp., since at this latitude this species is so far the only reported deep-sea octopus with one row of suckers, hence, $T$. rotunda is not distributed in Chilean waters as has been reported (Rocha 1997, Vega et al. 2001, Vega 2009). Furthermore, the specimen identified as G. antarctica (MNHNCL 300039) by Vega et al. (2001) from southern Chile corresponds to Graneledone sp. (Table 1).

Although some of the specimens have been found associated with hard grounds, like those present at methane seeps, no special adaptations to this type of habitat have been observed. We assume that the preference of this species for these sites is just a consequence of the locally enhanced abundance of potential prey and the availability of hard substrate generated by the carbonate reefs present at seep sites (Sellanes et al. 2008).

\section{ACKNOWLEDGMENTS}

We thank Janet Voight, Jan Strugnell and Jürgen GuerreroKommritz for their valuable comments of the early version of this manuscript. We are deeply indebted to captain and crew of AGOR Vidal Gormáz of the Chilean Navy, as well as scientific staff during VG07 cruise for their support at sea. We thank Sergio Letelier and Bernhard Hausdorf for help in examining specimens from the MNHNCL (Chile) and ZMH (Germany), and Milton Pedraza for collecting one specimen. FINANCIAL SUPPORT: This work was partially funded by grants to C.I. FONDECYT 3110152, to J.S., FONDECYT 1061217 and FONDECYT 1100166, and to E.P., ICM P05-002 and PFB-23. Support to M.C. Pardo-Gandarillas by a MECESUP-Chile Doctoral Fellowship are also acknowledged.

\section{LITERATURE CITED}

Aljanabi SM \& I Martinez. 1997. Universal and rapid saltextraction of high quality genomic DNA for PCR-based techniques. Nucleic Acids Research 25: 4692-4693.

Allcock AL, MA Collins \& M Vecchione. 2003. A redescription of Graneledone verrucosa (Verrill, 1881) (Octopoda: Octopodidae). Journal of Molluscan Studies 69: 135-143.

Allcock AL, JM Strugnell, P Prodöhl, U Piatkowski \& M Vecchione. 2007. A new species of Pareledone (Cephalopoda: Octopodidae) from the Antarctic Peninsula. Polar Biology 30: 883-893. 
Allcock AL, JM Strugnell \& MP Johnson. 2008. How useful are the recommended counts and indices in the systematics of the Octopodidae (Mollusca: Cephalopoda). Biological Journal of the Linnean Society 95: 205-218.

Allcock AL, I Barratt, M Eléaume, K Linse, MD Norman, PJ Smith, D Steinke, DW Stevens \& JM Strugnell. 2011. Cryptic speciation and the circumpolarity debate: A case study on endemic Southern Ocean octopuses using the COI barcode of life. Deep-Sea Research II 58: 242-249.

Farris JS, MKA Kallersjoäjersjo, AG Kluge \& C Bult. 1995. Constructing a significance test for incongruence. Systematic Biology 44: 570-572.

Felsenstein J. 1985. Confidence limits on phylogenies: an approach using the bootstrap. Evolution 39: 783-791.

Guerra A, AF González \& Y Cherel. 2000. Graneledone gonzalezi sp. nov. (Mollusca: Cephalopoda): a new octopod from the Iles Kerguelen. Antarctic Science 12: 33-40.

Guerra A, A Roura, MP Sieiro, JM Portela \& JL Del Río. 2012. New insights into the morphology, reproduction and distribution of the large-tuberculate octopus Graneledone macrotyla from the Patagonian slope. Scientia Marina 76: 319-328.

Guerrero-Kommritz J. 2000. A new species of Graneledone from the southwest Atlantic. Journal of Molluscan Studies 66: 543-549.

Guerrero-Kommritz J. 2006. Octopods (Cephalopoda: Octopoda) with uniserial suckers from the southwest Atlantic Ocean in the Zoological Museum Hamburg. Mitteilungen Hamburgisches Zoologisches Museum und Institut 103: 11-32.

Ibáñez CM, RD Sepúlveda \& J Chong. 2006. A new species of Benthoctopus Grimpe 1921 (Cephalopoda: Octopodidae) from the southeastern Pacific Ocean. Proceedings of the Biological Society of Washington 119: 355-364.

Ibáñez CM, PA Camus \& FJ Rocha. 2009. Diversity and distribution of cephalopod species of the coast off Chile. Marine Biology Research 5: 374-384.

Ibáñez CM, MC Pardo-Gandarillas, D Párraga, M Ziruelello \& J Sellanes. 2011. Cefalópodos recolectados en el talud continental de Chile central. Amici Molluscarum 19: 37-40.

Kubodera T \& T Okutani. 1994. Eledonine octopods from Southern Ocean: systematics and distribution. Antarctic Science 6: 205-214.

Norman MD \& FG Hochberg. 2005. The current state of Octopus taxonomy. Phuket Marine Biology Center Research Bulletin 66: 127-154.

O'Shea S. 1999. The marine fauna of New Zealand: Octopoda (Mollusca: Cephalopoda). NIWA. Biodiversity Memoir 112: 1-280.

Posada D. 2008. jModelTest: phylogenetic model averaging. Molecular Biology and Evolution 25: 1253-1256.
Rambaut A \& AJ Drummond. 2009. Tracer v1.5. [on line] < http//tree.bio.ed.ac.uk/software/tracer>

Rocha F. 1997. Cephalopods in Chilean waters, a review. Malacological Review 30: 101-113.

Ronquist F, M Teslenko, $P$ van der Mark, D Ayres, A Darling, S Höhna, B Larget, L Liu, MA Suchard \& JP Huelsenbeck. 2012. MrBayes 3.2: Efficient Bayesian phylogenetic inference and model choice across a large model space. Systematic Biology <doi: 10.1093/sysbio/sys029>

Roper CFE \& GL Voss. 1983. Guidelines for taxonomic descriptions of cephalopod species. Memoirs of the National Museum of Victoria 44: 49-63.

Roper CFE, MJ Sweeney \& CE Nauen. 1984. Cephalopods of the world. An annotated and illustrated catalogue of species of interest to fisheries. FAO Fisheries Synopsis 125(3): 1-277.

Sellanes J, E Quiroga \& VA Gallardo. 2004. First direct evidences of methane seepage and associated chemosynthetic communities in the bathyal zone off Chile. Journal of the Marine Biological Association of the United Kingdom 84: 1065-1066.

Sellanes J, E Quiroga \& C Neira. 2008. Megafaunal community structure and trophic relationships of the recently discovered Concepción Methane Seep Area (Chile, $\sim 36^{\circ}$ S). ICES Journal of Marine Science 65: 1102-1111.

Söller R, K Warnke, U Saint-Paul \& D Blohm. 2000. Sequence divergence of mitochondrial DNA indicates cryptic biodiversity in Octopus vulgaris and supports the taxonomic distinctiveness of Octopus mimus (Cephalopoda: Octopodidae). Marine Biology 136: 29-35.

Strugnell JM, AL Allcock \& MA Collins. 2008a. Molecular evolutionary relationships of the octopodid genus Thaumeledone (Cephalopoda: Octopodidae) from the Southern Ocean. Antarctic Science 20: 245-251.

Strugnell JM, AD Rogers, PA Prodöhl, MA Collins \& AL Allcock. 2008b. The thermohaline expressway: the Southern Ocean as a centre of origin for deep-sea octopuses. Cladistics 24: 853-860.

Sweeney MJ. 2001. Current Classification of Recent Cephalopoda. [on line] <http://sirismm.si.edu/cephs/ newclass.pdf $>$

Swofford DL. 2002. PAUP*: Phylogenetic Analysis Using Parsimony (* and Other Methods), Version 4. Sinauer Associations, Sunderland. [CD ROM]

Tamura K, D Peterson, N Peterson, G Stecher, M Nei \& S Kumar. 2011. MEGA5: Molecular Evolutionary Genetics Analysis using maximum likelihood, evolutionary distance, and maximum parsimony methods. Molecular Biology and Evolution 8: 2731-2739.

Thore S. 1959. Cephalopoda. Reports of the Lund University Chile Expeditions 1948-49 33: 1-20. 
Vega MA. 2009. Sistemática, biogeografía y pesquería de cefalópodos de aguas chilenas, 288 pp. RIL Editores, Santiago.

Vega MA, S Letelier \& E Carreño. 2001. Colección de cefalópodos del Museo Nacional de Historia Natural: catálogo especies de aguas chilenas. Boletín, Museo Nacional de Historia Natural Santiago Chile 57: 1-88.

Voight JR. 1997. Cladistic analysis of the order Octopoda based on anatomical characters. Journal of Molluscan Studies 63: 311-325.

Voight JR. 2000a. The distribution of octopuses of Graneledone (Cephalopoda: Octopodidae) in reference to deep-sea features. Malacologia 42: 63-74.
Voight JR. 2000b. A deep-sea octopus (Graneledone cf. boreopacifica) as a shell-crushing hydrothermal vent predator. Journal of Zoology of London 252: 335-341.

Voss GL. 1976. Two new species of octopods of the genus Graneledone (Mollusca: Cephalopoda) from the southern Ocean. Proceedings of the Biological Society of Washington 88: 447-458.

Voss GL \& WG Pearcy. 1990. Deep-water octopods (Mollusca: Cephalopoda) of the Northeastern Pacific. Proceedings of the California Academy of Science 47: 47-94.

Received 20 June 2012 and accepted 4 October 2012

Associate Editor: Mauricio Landaeta D. 